\title{
Ethical Sensitivity and Moral Considerations of Accounting Students Based on Accounting Ethics Education
}

\author{
Budi Astuti, Witri Gustina, Rina Yuniarti, Yusmaniarti, Nensi Yuniarti Zs \\ Universitas Muhammadiyah Bengkulu \\ Email: budiastuti@umb.ac.id, witri.gustiana.98@gmail.com, rinayuniarti@umb.ac.id, \\ yusmaniarti@umb.ac.id, yuniartinensi@gmail.com
}

\begin{abstract}
ARTICLE INFO
Received

05 September 2021

Revision

18 September 2021

Approved

21 September 2021

Keywords:

Ethical Sensitivity;

Moral

Considerations;

Accounting Ethics

Education

\section{ABSTRACT}

The purpose of this study was to examine the differences in ethical sensitivity and moral considerations of students based on semester and gender. The population of this study was Accounting Students at the University of Muhammadiyah Bengkulu. Sampling using the purposive sampling method to obtain as many as 87 respondents. The method of data collection is the questionnaire method. The data analysis technique used descriptive statistical analysis, data quality test, and hypothesis testing. The result of this research is that there is no difference between the ability of students who have received accounting ethics education in identifying ethical dilemmas compared to the ability of students who have not received accounting ethics education. The ability of female students who have received accounting ethics education is higher in identifying ethical dilemmas than the ability of male students. The ability of students who have received accounting ethics education is higher in making moral judgments than the ability of students who have not received accounting ethics education. There is no difference between the ability of female students who have received accounting ethics education better in making moral judgments than the ability of male students.
\end{abstract}

\section{INTRODUCTION}

The public accounting profession is a profession that uses its expertise in the field of accounting to make accounting information in making business decisions for companies (Ananto \& Januarti, 2016). The public accounting profession plays a role in the sustainability of a company. A public accountant must have good morals and professional ethics. The Indonesian Institute of Certified Public Accountants (IAPI) makes rules regarding the code of ethics of the public accounting profession that must be obeyed by all public accountants. This code of ethics contains rules that must be obeyed when public accountants do their work to remind that the responsibility of auditors is very important in protecting the public interest, especially in the form of the availability of quality financial information (Fiske \& Taylor, 2013).

auditors must also be able to detect scandalous activities before they develop into very detrimental accounting (Norbarani \& Rahardjo, 2012). An auditor who has an attitude of competence in his audit assignments can make it easier for him to detect fraud by (Respati, 2019).

The case that became the world's spotlight was the bankruptcy of the largest energy company in the United States, Enron Corporation. The error in giving the opinion issued by the auditor made one of the public accountants (big five), namely Arthur Andersen involved and quit. In Indonesia, a similar case also occurred, where the ministry of finance stated that two public accountants who audited the financial statements of PT Sunprima Nusantara Pemfundan (SNP)

$\begin{array}{ll}\text { How To Cite: } & \text { Astuti, B., et. al. (2021) Ethical Sensitivity And Moral Considerations of Accounting Students } \\ & \text { Based on Accounting Ethics Education. Journal of Social Science 2(5). } \\ & \text { https://doi.org/10.46799/jss.v2i5.218 }\end{array}$


Finance, namely public accountants (Amalia, Sutrisno, \& Baridwan, 2019), had violated professional auditing standards because they had given opinions that were not in accordance with actual conditions. The existence of these cases clearly shows that there are still many auditors who violate professional ethics. ethics should be instilled as early as possible to create a moral auditor character. or it could be due to lack of experience. Because experience can expand a person's knowledge and the more experience he has, the faster and more skilled he will be in his work. (Rahmawati \& Usman, 2014) And that case can be prevented by triangulation carried out in this study by collecting the same data with different techniques. In this way, it not only enhances the validity but also the results of the study can be deepened (Lukman \& Harun, 2018).

Accounting students are prospective accountants, so it is very necessary for academics to improve the education curriculum on ethics that will be faced in identifying a problem when an ethical dilemma occurs. (Sari, 2014) argues that accountants are now professionals in the future and with a good ethical education it is expected to benefit the profession in the long term.

Violation cases occur a lot, resulting in a decrease in public confidence in the professionalism of public accountants. Efforts are made to restore public trust through education where prospective accountants know and learn accounting science. A good world of education will shape students into prospective accountants who have a professional attitude based on moral and ethical standards (Apriyana \& Puspita, 2018). This study is a replication of the research conducted by (Bloodgood et al., 2013) using two of the Four Component Rest Models (1986), namely ethical sensitivity and moral considerations. This research was carried out again with the intention of whether the results obtained would be the same as previous studies using the same theory. In addition, research on the influence of the moral intensity component on the decisionmaking process is still little done.

(Kennedy et al., 2018), found that the ability of accounting students who had received accounting ethics education was higher in identifying ethical problems (ethical sensitivity) than the ability of students who had not received accounting ethics education. The results of this study are not in line with research conducted by (Hutahahean \& Hasnawati, 2015) which revealed that gender had no significant effect on the ethical behavior of accounting students. This means that at this time women and men may both have deficiencies in reasoning ethical behavior, many of them are competing in the career field, seeking power, seeking wealth without thinking about ethical violations in it. The purpose of this study was to re-examine the differences in ethical sensitivity and moral considerations of students based on semester and gender.

\section{METHOD}

Comparative causal research which is an ex post facto type of research. This study uses a quantitative approach. Ex post facto research is research that aims to find the causes that allow changes in behavior, symptoms or phenomena caused by an event, behavior or things that cause changes in the independent variables which as a whole have occurred. The research was conducted at the Faculty of Economics and Business, University of Muhammadiyah Bengkulu. The population in this study were students of the Accounting Study Program semester 2 to semester 8, with a sampling technique using purposive sampling. (Jahja, 2013) purposive sampling is a technique where sampling is based on certain considerations or criteria. In this study several criteria were proposed by the researcher as a sample. The technique of collecting data is through an online questionnaire which is distributed using a google form. Data analysis using SPSS (Statistical Package For Social Science) program.

\section{RESULTS AND DISCUSSION}

\section{A. Data Analysis}

Of the 87 respondents who filled out questionnaires online, there were 87 questionnaires or $100 \%$ that could be processed,

Based on validity tests conducted with pearson correlation, it was obtained that all indicators in the variables studied were declared valid with significance values $<0,05$. Then from the results of 
reliability test with Cronbach Alpha formula, obtained the result that all variables in the study were declared raliabel with cronbach alpha value $>0,06$.

Table 1

Validity Test Results

\begin{tabular}{ccccc}
\hline Variable & Case & Anti Image & $\begin{array}{c}\text { KMO and } \\
\text { Bartlett Test }\end{array}$ & desc \\
\hline Ethical & Case 1 & 0.771 & & Valid \\
Sensitivity & Case 2 & 0.747 & 0.767 & Valid \\
& Case 3 & 0.847 & Sig 0.000 & Valid \\
& Case 4 & 0.786 & & Valid \\
& Case 5 & 0.714 & & Valid \\
& Case 6 & 0.772 & & Valid \\
& Case 7 & 0.631 & & Valid \\
Moral & Case 8 & 0.869 & & Valid \\
Considerations & Stage 5A & 0.757 & & Valid \\
& Stage 5B & 0.662 & 0.667 & Valid \\
& Stage 6 & 0.621 & Sig 0.000 & Valid \\
\hline
\end{tabular}

Source: Processed data (2021)

Based on Table 1, the results of the validity test show a positive correlation at the 0.01 and 0.05 levels. In other words, all the questions in the questionnaire were able to reveal the level of ethical sensitivity of accounting students. All items in this questionnaire are also valid with KMO 0.767 and KMO MSA for all items greater than 0.5 so that factor analysis can be carried out. The Bartlett test value with a significance of 0.000 , it can be concluded that the factor analysis test can be continued. The moral considerations of all items in this questionnaire are also valid with $\mathrm{KMO}>$ 0.667 and KMO MSA for all items greater than 0.5 so that factor analysis can be carried out. Likewise, the Bartlett test value with a significance of 0.000 , it can be concluded that the factor analysis test can be continued.
Tabel 2

Reliability Test

\begin{tabular}{cccc}
\hline Variable & $\begin{array}{c}\text { Cronbach's } \\
\text { Alpha }\end{array}$ & $\begin{array}{c}\text { N of } \\
\text { Items }\end{array}$ & Information \\
\hline $\begin{array}{c}\text { Ethical } \\
\text { Sensitivity } \\
\begin{array}{c}\text { Moral } \\
\text { Considerations }\end{array}\end{array}$ & 0.794 & 8 & Reliable \\
\hline
\end{tabular}

Source: Processed data (2021)

Based on Table 2, it is known that the ethical sensitivity and moral considerations have a Cronbach Alpha value greater than 0.60 , namely 0.794 and 0.604. This means that the research instrument is reliable and can be analyzed.

\section{B. Hypothesis Test}

The hypothesis test used in this study used independent sample t-test analysis. The following results of the analysis of hypothesis testing are shown in Tables 3 and 4. 
Group Statistic

\begin{tabular}{|c|c|c|c|c|c|c|}
\hline Variabel & Dimensi & Group & $\mathbf{N}$ & Mean & $\begin{array}{c}\text { Std. } \\
\text { Deviation }\end{array}$ & $\begin{array}{l}\text { Std. Error } \\
\text { Mean }\end{array}$ \\
\hline Ethical & SMT & SMT $2 \& 4$ & 38 & 43.74 & 9.934 & 1.612 \\
\hline \multirow[t]{3}{*}{ Sensitivity } & & SMT $6 \& 8$ & 49 & 44.65 & 4.776 & 0.682 \\
\hline & JK & L & 49 & 46.06 & 6.609 & 0.944 \\
\hline & & $\mathrm{P}$ & 38 & 41.92 & 7.886 & 1.279 \\
\hline & SMT & SMT $2 \& 4$ & 38 & 202.32 & 21.968 & 3.564 \\
\hline \multirow[t]{3}{*}{ Considerations } & & SMT $6 \& 8$ & 49 & 191.57 & 24.534 & 3.505 \\
\hline & JK & L & 49 & 197.31 & 21.806 & 3.115 \\
\hline & & $P$ & 38 & 194.92 & 26.647 & 4.323 \\
\hline
\end{tabular}

Source: Processed data (2021)

Tabel 6

Hasil Uji Hipotesis

Independent Sample T-Test

\begin{tabular}{cccccc}
\hline Variabel & Dimensi & t & Df & $\begin{array}{c}\text { Sig.(2- } \\
\text { tailed) }\end{array}$ & Ket \\
\hline $\begin{array}{c}\text { Sensitivitas } \\
\text { Etis }\end{array}$ & Semester & $-0,567$ & 85 & 0.572 & H1a rejected \\
& & & & & \\
$\begin{array}{c}\text { Moral } \\
\text { Considerations }\end{array}$ & Sender & 2.663 & 85 & 0.009 & H1b accepted \\
& & 2.120 & 85 & 0.037 & H2a accepted \\
& Gender & 0.459 & 85 & 0.647 & H2b rejected \\
\hline & \multicolumn{2}{r}{ Source: Processed data (2021) }
\end{tabular}

Based on Table 6 , the results of testing hypothesis 1a were carried out to determine the difference in ethical sensitivity of accounting students at the University of Muhammadiyah Bengkulu based on semester level. The analysis of the t-test difference test uses the assumption of equal variance not assumed and appears at a t-value of -0.567 with a significant probability of 0.572 (2-tailed) which means the average ethical sensitivity between the 2nd and 4th semester student groups and the 6th and 8th semester student groups. not significant, it can be concluded that hypothesis $1 \mathrm{a}$ is not acceptable.

These results prove that ethics education taught in the accounting program does not have a positive impact on improving the ability of 6th and 8th semester students, it is possible that students have problems understanding the questions. The results are not in line with the (Kennedy et al., 2018) which revealed that offering ethical training was really able to increase the sensitivity of accounting students. However, this study is in line with Chocolate (2013), which revealed that there is no relationship between ethics education and students' ethical level, whether or not they receive ethics education, accounting students show higher ethical awareness because ethical education does not always increase ethical behavior.

Furthermore, testing the ethical sensitivity of accounting students after receiving ethics education based on gender. Based on Table 4.9, the analysis of the t-test difference test uses the assumption of equal variance assumed and appears at a t-value of 2.663 with a significant probability of 0.009 (2-tailed) > 0.05 , which means that there is a difference between the average ethical sensitivity between male students. and female students, it can be concluded that hypothesis $1 \mathrm{~b}$ is accepted. The results of this study are similar to the research conducted by (Bloodgood et al., 2013) which revealed that women tend to have higher ethical awareness than men, because female students are more likely to behave ethically in academic settings.

Testing Testing of hypothesis $2 a$ was 
conducted to determine the difference in moral judgment of accounting students at the University of Muhammadiyah Bengkulu based on semester level. Based on Table 4.9, the analysis of the t-test difference test uses the assumption of equal variance assumed and appears at a t-value of 2.120 with a significant probability of 0.037 (2tailed) $>0.05$, which means the average moral judgment between the 2nd and 4th semester student groups is higher. low with the 6th and 8th semester students group being different, in other words significant, it can be concluded that hypothesis $2 \mathrm{a}$ is accepted.

This shows that the accounting ethics education that has been obtained by the 6th and 8th semester student groups is able to increase the level of students' moral judgment when faced with ethical dilemmas. The results of this study are in line with (Kusuma, Setiono, \& Poli, 2018), which states that the ability to make moral judgments of accounting students who have received ethics education is higher than accounting students who have not received ethics education. Accounting ethics education is an important factor that influences students' moral judgment because it has the potential to have an impact on individual behavior, intentions and decisions in dealing with ethical dilemmas.

Hypothesis $2 \mathrm{~b}$ testing was conducted to determine differences in the ability to make moral judgments on accounting students at the Muhammadiyah University of Bengkulu based on gender. Based on Table 4.9, the analysis of the t-test difference test uses the assumption of equal variance not assumed and appears at the t-value of 0.459 with a significant probability of 0.647 (2-tailed) which means that there is no difference between the average moral considerations of male and female students. , it can be concluded that hypothesis $2 \mathrm{~b}$ cannot be accepted.

The results of this study are in line with (Hutahaean et al., 2021) which revealed that gender had no significant effect on the ethical behavior of accounting students. This proves that women and men may both have deficiencies in reasoning ethical behavior, many of them competing in the career field, seeking power, seeking wealth without thinking about ethical violations in it.

\section{CONCLUSION}

1) This study aims to determine whether there are differences in ethical sensitivity and moral considerations of accounting students based on semester level and gender. Based on the results of data analysis, the following conclusions were obtained:2) Based on the results of statistical analysis revealed that there is no difference between the ability of accounting students who have received accounting ethics education better in identifying ethical problems (ethical sensitivity) than the ability of students who have not received accounting ethics education.3) Based on the results of statistical analysis revealed that the ability of female students after receiving accounting ethics education is higher in identifying ethical problems (ethical sensitivity) than the ability of male students.4) Based on the results of statistical analysis revealed that the ability of students who have received accounting ethics education is higher in making moral judgments than the ability of students who have not received accounting ethics education.5) Based on the results of statistical analysis revealed that there is no difference between the abilities of female students who have received accounting ethics education are better at making moral judgments than the abilities of male students.

\section{a. Implication}

Theoretically, this research has the implication that the dimension of moral intensity can be used by accounting educators (lecturers) especially as a tool to discuss cases related to ethical issues, so as to increase the understanding of accounting students in assessing ethical or not an action. So that the gap between accounting graduates and people's expectations does not experience a large gap.

\section{b. Research Limitations}

This study has a limitation, namely that it only examines 2 of the 4 components of the ethical decisionmaking model. This is due to the lack of 
research on the third component, namely moral motivation which makes it difficult for researchers to conduct research development. While the fourth component is a moral action that is difficult to measure because moral action is the final stage of the ethical decisionmaking process from action to behavior. For further research, the researcher suggests that research that examines moral intensity by using cases is carried out using the experimental method, so that the results obtained are as expected.

\section{REFERENCES}

Amalia, Firda Ayu, Sutrisno, Sutrisno, \& Baridwan, Zaki. (2019). Audit Quality: Does Time Pressure Influence Independence And Audit Procedure Compliance Of Auditor? Journal of Accounting And Investment, 20(1), 130-144.Google Scholar

Ananto, Nugroho Dwi, \& Januarti, Indira. (2016). Analisis Faktor Internal Dan Eksternal Yang Mempengaruhi Persepsi Mahasiswa Akuntansi Terhadap Tindakan Plagiarisme Dengan Tekanan Sebagai Variabel Moderating. Fakultas Ekonomika Dan Bisnis. Google Scholar

Apriyana, Kiki, \& Puspita, Lisa Martiah Nila. (2018). Sensitivitas Etis Dan Pertimbangan Moral Mahasiswa Akuntansi Terhadap Dilema Bisnis. Jurnal Akuntansi, 8(1), 26-40. Google Scholar

Bloodgood, Bonny, Inokuchi, Derek, Shawver, Willis, Olson, Kristina, Hoffman, Rosanne, Cohen, Elyse, Sarmiento, Kelly, \& Muthuswamy, Kavitha. (2013). Exploration Of Awareness, Knowledge, And Perceptions of Traumatic Brain Injury Among American Youth Athletes And Their Parents. Journal of Adolescent Health, 53(1), 34-39. Google Scholar

Fiske, Susan T., \& Taylor, Shelley E. (2013). Social Cognition: From Brains To Culture. Sage. Google Scholar
Hutahaean, Jeperson, Purba, Ramen A., Siagian, Yessica, Heriyani, Nofitri, St Amina, H. Umar, Syah, Arridha Zikra, Ardiana, Dewa Putu Yudhi, \& Simarmata, Janner. (2021). Pengantar Sistem Informasi Manajemen. Yayasan Kita Menulis. Google Scholar

Hutahahean, M. Umar Bakri, \& Hasnawati, Hasnawati. (2015). Pengaruh Gender, Religiusitas Dan Prestasi Belajar Terhadap Perilaku Etis Akuntan Masa Depan (Studi Pada Mahasiswa Akuntansi Perguruan Tinggi Swasta Di Wilayah Dki Jakarta). Jurnal Akuntansi Trisakti, 2(1), 49-66. Google Scholar

Jahja, Adi Susilo. (2013). Metodologi Penelitian Bisnis. Google Scholar

Kennedy, Jamie C., Dunlop, Boadie W., Craighead, Linda W., Nemeroff, Charles B., Mayberg, Helen S., \& Craighead, W. Edward. (2018). Follow-Up Of Monotherapy Remitters In The Predict Study: Maintenance Treatment Outcomes And Clinical Predictors Of Recurrence. Journal Of Consulting And Clinical Psychology, 86(2), 189. Google Scholar

Kusuma, Nunuk Widyawati, Setiono, Benny Agus, \& Poli, Sofyan. (2018). Pengaruh Kualitas Pelayanan Jasa Pemanduan Terhadap Kepuasan Pelanggan Di Pt Pelabuhan Indonesia Iii (Persero) Cabang Tanjung Perak Surabaya. Jurnal Aplikasi Pelayaran Dan Kepelabuhanan, 6(1), 41-51. Google Scholar

Lukman, Hendro, \& Harun, Viviani. (2018). Faktor Yang Mempengaruhi Deteksi Kecurangan Dalam Persepsi Auditor Eksternal Dan Auditor Internal. Jurnal Akuntansi, 22(2), 255-265. Google Scholar

Norbarani, Listiana, \& Rahardjo, Shiddiq Nur. (2012). Pendeteksian Kecurangan Laporan Keuangan Dengan Analisis Fraud Triangle Yang Diadopsi Dalam Sas No. 99. Fakultas Ekonomika Dan Bisnis. Google Scholar

Rahmawati, Rahmawati, \& Usman, Halim. 
(2014). Pengaruh Beban Kerja Dan Pengalaman Auditor Dalam Mendeteksi Kecurangan. Journal Of Accounting And Investment, 15(1), 68-76. Google Scholar

Respati, Widagdo. (2019). Pengaruh Skeptisme Profesional, Independensi Dan Kompetensi Terhadap Kemampuan Auditor Mendeteksi Kecurangan (Studi Empiris Pada Kantor Akuntan Publik Di Wilayah Dki Jakarta). Skripsi-2019. Google Scholar
Sari, Lita Permata. (2014). Pengaruh Muatan Etika Dalam Pendidikan Akuntansi Terhadap Persepsi Etika Mahasiswa. Jurnal Akuntansi Multiparadigma, 3(3), 380-392. Google Scholar

\section{Copyright holder :}

Budi Astuti, Witri Gustina, Rina Yuniarti, Yusmaniarti, Nensi Yuniarti Zs (2021)

First publication right :

Journal of Social Science

This article is licensed under:

(c) (i) (2) 